\title{
STK35 wt Allele
}

National Cancer Institute

\section{Source}

National Cancer Institute. STK35 wt Allele. NCI Thesaurus. Code C122739.

Human ST K35 wild-type allele is located in the vicinity of 20p13 and is approximately 75

$\mathrm{kb}$ in length. This allele, which encodes serine/threonine-protein kinase 35 protein, may be a regulator of actin stress fibers in nonmuscle cells. 